\title{
Representation of Disability Achievements in Television Talk Show Programs
}

\section{Representasi para Disabilitas Berprestasi dalam Program Talk Show Televisi}

\author{
Retno Manuhoro Setyowati ${ }^{1}$, Errika Dwi Setya Watie ${ }^{1}$, Ami Saptiyono ${ }^{1}$ \\ ${ }^{1}$ Department of Communication, Faculty of Information Technology and \\ Communication, Universitas Semarang, Jl. Soekarno Hatta Tlogosari Semarang, Central \\ Java 59160, Indonesia \\ *Corresponding author, e-mail: retnomanuhoro@usm.ac.id
}

\begin{abstract}
This study looks at how the disability presented in television talk shows program. It's important because the diffables in the media are often presented biased, causing misunderstandings. This can have an impact on the fulfillment of their rights by the government and also their social position. The use of representation theory to explain the process of media representation and interpret audience concepts using language. The analysis of research uses the Saussure semiotic method, because representation is closely related to the appearance of images, and other components, which are interrelated between markers and marked ones. The results showed that the media still placed disability as an object of inspiration, an object of pity should get a lot of appreciation in sports matches because of physical limitations. The media quickly found momentum to 'sell' disability stories that inspire. Achievement of disabilities is always related to money, not based on their rights.
\end{abstract}

Keywords: Representation, Disability, Talk Show, Television.

\begin{abstract}
Abstrak
Penelitian ini melihat bagaimana disabilitas disajikan dalam program talk show televisi. Hal ini penting karena para difabel di media sering disajikan secara bias, sehingga menimbulkan kesalahpahaman. Hal ini bisa berdampak pada pemenuhan hak mereka oleh pemerintah dan juga posisi sosial mereka. Penggunaan teori representasi untuk menjelaskan proses representasi media dan menafsirkan konsep audiens dengan menggunakan bahasa. Analisis penelitian menggunakan metode semiotik Saussure, karena representasi terkait erat dengan penampilan gambar, dan komponen lainnya, yang saling terkait antara penanda dan yang ditandai. Hasil penelitian menunjukkan bahwa media masih saja menempatkan disabilitas sebagai objek inspirasi, objek yang dikasihani, harus mendapatkan banyak apresiasi dalam pertandingan olahraga karena keterbatasan fisik. Media cepat menemukan momentum untuk 'menjual' kisahkisah disabilitas yang menginspirasi. Pencapaian penyandang disabilitas selalu dikaitkan dengan uang, bukan berdasarkan hak mereka.
\end{abstract}

Kata Kunci: Representasi, Disabilitas, Talk Show, Televisi.

\section{Introduction}

In daily life, our encounter with persons with disabilities in the dynamics of life seems to be very limited, because to blend in society and activities as other humans are not well facilitated. This analysis arises from the Remotivi Mass Media Study Institute which confirms that between persons with disabilities and the community there is still distance and rarely intersects because they are not facilitated by the environment, and many obstacles (Maulana, 2019). Whereas the existence of disabilities in Indonesia, based 
on notes from the World Health Organization (WHO), there is at least 10 percent of the total population of Indonesian people (Anonymous, 2019).

The Ministry of Social Affairs of the Republic of Indonesia--Data and Information Center recorded 11 million persons with disabilities in the past 10 years, while data from the Ministry of Manpower and Transmigration of the Republic of Indonesia totaled more than 7 million people. The latest data is obtained from the 2015 Central Bureau of Statistics Inter-Population Survey (SUPAS BPS), which is 8.56 percent of the population is disabled in Indonesia (Salim, 2018). Inaccurate and the lack of up-to-date data that should be mapped by the government, further confirms that disability is not yet given priority in accessing their rights including socializing.

Disability is far from common view, its activity is blocked by structure, so it cannot move broadly and independently. The Mass Media Study from Remotivi also stated clearly that in the community, vehicles that bring people with disabilities and nondisabled people together are also relatively rare, even almost non-existent. The mass media has finally become one of the 'helpers,' the bridge that mediates between the lives of people with disabilities and people's curiosity through the screen. But this does not necessarily become a wise middle ground, because the appearance of diffable in the media often causes two problems, namely under-represented and misinterpreted (Thaniago, 2018).

Disability often does not get a portion of impressions with a lot of frequency. The appearance of diffable in the media in various programs often does not give a wrong understanding. This was demonstrated by Zhang and Haller in their quantitative study entitled 'Consuming Image: How Mass Media Impacts the Identity of People with Disabilities,' which connects the impact of media reporting on persons with disabilities on their identities. Instead of giving rise to additional insights, the presence of diffable in the media actually seems less close to everyday reality. This situation can certainly have a different impact on the fulfillment of their rights by the government and also their social position in society (Zhang \& Haller, 2013).

The presence of diffable on television is not always fully portrayed. Without being realized by the diffable, the media gave rise to the diffable in various stereotypes, namely as objects of pity, objects of inspiration, joke material, or asexual beings. In 1991, an activist who diligently defended the rights of disabled people in the UK, as well as critically minded writer Paul Hunt, stated that the media often portrayed the diffable as an object of humor, inspiration and a tool of compassion for exploitation. According to Hunt, the stereotypes that the media display towards the diffable are often only to provoke laughter. For example the emergence of characters who were laughed at such as Daus Mini, Adul, Hendrik Ceper and several other comedian names who blatantly made their short body's physical condition the target of mere jokes (Wood, 2014).

Stella Young, a diffable journalist and activist defending rights for the diffable, even coined the term 'inspiration porn' to show her concern for her fellow disabled friends who were often forced by the media to be presented as figures who always inspire others. Young also aggressively voiced his concerns about people's views of the disabled and made this a stand-up comedy. This Australian comic expressly conveyed the message that he was not an inspirational figure in his satire comedy with the final sentence "I'm not your inspiration." He considered, the media often highlighted aspects that seemed to be life-encouraging for others, but often the media also negated the humanitarian aspects of the diffable as the speaker because it was as if the life of a diffable was only to inspire it (TED, 2014). 
In line with this, researchers see that there are still television shows in Indonesia that display stereotypical types such as those observed by Paul Hunt (Hunt, 1966). In the researcher's notes, persons with disabilities are more often featured in talk shows or talk shows. Until now, talk show programs that are still actively running on-screen are found in 5 national television stations namely Trans 7, Trans TV, Metro TV, Net TV, and TV One. The Trans 7 television station even has a talk show program which is divided into several program names such as 'Mata Najwa,' 'Rumah Uya,' and 'Hitam Putih.' But if you see the momentum that coincides with the 2018 Asian Para Games event, then the talk show program is the 'Hitam Putih' most diligent in displaying people with disabilities.

This is why this study chose the talk show 'Hitam Putih' as the object of research. The selection of this talk show 'Hitam Putih' also considers the consistency of a program in presenting its speakers. The 'Hitam Putih' resource person is not only from officials (as is typical of 'Mata Najwa') but also brings guests from all walks of life as long as it is considered to contain informative, sensational, inspirational and contemporary elements.

According to the observations of researchers, 'Hitam Putih' has displayed the figure of the diffable, well before the busy momentum of the sports championship for the diffable. Even the end of the 2018 Asian Para Games held on 6 to 13 October 2018 did not make the talk show owned by the national television station Trans 7 immediately stop presenting speakers with disabilities. In the following months until February 2019, 'Hitam Putih' consistently invited people with disabilities as their speakers. In terms of ratings and shares, the talk show 'Hitam Putih' during the 2018 Disability Games, the data from the Nielsen website recorded a rating of 0.85 and a share of 4.48 with a total audience of 72.680 viewers. This was recorded higher than the talk show 'Kick Andy' on Metro TV at the same time.

The Talk Show program 'Hitam Putih' is guided by Deddy Corbuzier, an artist who is now better known as a mentalist and motivator. In a special period that utilizes the momentum of the 2018 Asian Disabilities Games or Asian Para Games 2018, they invited disabled athletes. The talk show invited six athletes from three different sports. Three women with impaired vision won gold from athletics, two blind male athletes each with 3 gold from chess, and one badminton athlete winning 2 silver Asian Para Games 2018. The glass screen was filled with ups and downs for the struggles of athletes diffable.

Meanwhile, this research seeks the development of knowledge from previous studies, so that the ultimate goal of this study is to find out if there is a renewal of the media's perspective on the disabled, especially in the fulfillment of their rights as human beings or whether it is still the same, even the portion of its appearance is still relatively small so vulnerable misunderstanding of the person with disabilities. One of the research findings that is used as a reference is 'Consuming Image: How Mass Media Acts the Identity of People with Disabilities' by Ling Ling Zhang and Beth Heller. The research is a quantitative study that looks for whether there is a relationship between media reporting and the identity of persons with disabilities, the average media is still described conventionally as stereotyped by Paul Hunt, namely poor, poor and pitiful (Zhang \& Haller, 2013). The media can form a large force in society. The media influences how we think about things and how we respond to the world. The media, regardless of the media content, requires us to think critically and creatively about the media we consume, how the media affect us as individuals, and how the media shape our culture and society (Syahputra, 2013). However, television as a type of media will be transformed into a figure-viewing machine that is considered to have an attraction and is able to captivate its 
viewers. Television must be able to bind the attention of its audience, including inviting performers who are considered to be able to increase 'ratings' (Baskin, 2006).

The diffable as the performers, as well as the disabled, both of them cannot be missed as the audience who must-watch television shows. The question of how the diffable representation displayed by the media needs to be discussed and researched. Therefore, the theory used in this study is the representation theory. In his theory, Stuart Hall stated representation to be the most important thing in a process. In culture the meanings produced are then exchanged between group members. In summary, the representation theory helps researchers interpret concepts in the minds of the audience by using language aids (Hall, 1997). In addition to language and meaning, concepts, signs are also components of this theory. While the signs can represent concepts that have been embedded in the human brain, then form a meaning system in culture (meaning system).

This is apparent in Watie's research entitled 'Representasi Wanita dalam Media Massa Masa Kini (Representation of Women in Today's Mass Media)' about how the media present a woman's figure to an audience which often raises negative stereotypes in society (Watie, 2010). In the article, reviewed about the representation of women in the mass media today, as well as the stereotype that emerged as the effect of the representation made by the mass media on women. Watie in the article uses the representative theory of Stuart Hall and Barthes Semiotics and the method content analysis in her research (Watie, 2010), while in this study, the authors review the representation of persons with disabilities in talk shows and the effects that emerge as a result of the shows using Stuart Hall's representative theory is the same as Watie's research, but it uses Sausser's semiotic theory and interactive analysis method that distinguishes this article from the previous research.

In addition to Stuart Hall's representation theory, researchers also use semiotic analysis tools. As in the research 'Representation of Orientalism in Sunsilk Print Advertising' by Nurcahya and friends, reviewing the symbols used in representing oriental beauty in a print ad using Roland Barthes's semiotic theory (Nurcahya, Hafiar, \& Nugraha, 2018). In this study, the author also uses semiotics to analyze the signs that appear in the broadcast, but related to the diffable, using Saussure's unique semiotics is characterized by the terms 'signifier' and 'signified,' both of which are cultural results. The relationship between the two is arbiter so the marker must be studied first so that the code appears to help interpret the meaning (Saussure, 1966; Sobur, 2009, 2011, 2016). Also known as the term signification which is a process of giving meaning to the sign.

\section{Method}

This type of research is descriptive qualitative so that it can provide a picture or understanding of something. In this case, the context of research is of high concern (Bungin, 2012; Moeloeng, 2017; Sugiyono, 2009). The sample shown in this study was the talk show 'Hitam Putih' special episode of the Asian Para Games Athlete on October 16, 2018, with resource persons of six athletes from three different sports. Three women (Putri Aulia, Ni Made Arianti Putri and Endang Sari Sitorus), with visual impairment, gold medalists from the athletics branch; two male athletes who are blind, each winning 3 gold from chess (Hendi Wirawan and Edy Suryanto), and one badminton athlete winning 2 silver Asian Para Games 2018 (Suryo Nugroho) (Trans 7 Official, 2018).

This analysis technique consists of three-step components, according to Miles and Huberman's interactive analysis technique (Bungin, 2012; Moeloeng, 2017; Sugiyono, 2009): 1). Data reduction. Selecting from the scenes existing, whichever scene is the 
sample of research based on purposive sampling in this study, which requires a category scene that is displaying the disabled, holding sports equipment and or achievement results, the subjects with disabilities smile. Whereas for dialogue (verbal) use categories that review flashbacks because of blindness, struggle for achievement, prizes or bonuses given as a reward for achievement. 2). Data Presentation. The presentation of data is done by first analyzing data with Saussure's semiotics. 3). Withdrawal of Conclusions. Based on the data that has been analyzed, the researcher then draws conclusions related to the representation that appears about the diffable through the 'Hitam Putih' show with representation from Stuart Hall.

The research was conducted at the Universitas Semarang, to facilitate the coordination and discussion of the research team. Research subjects basically can be accessed in many places, because it is stored on youtube. The research subjects wereTalk Show on a 'Hitam Putih' special episode of Asian Para Games Athlete on October 16, 2018 , the video can be accessed again via youtube.

\section{Results and Discussion}

Analysis of the discussion uses the stages of representation with the approach of the sign sciences of Saussure's semiotics, namely the sign consisting of 'signifier' and 'signified' both in scenes and dialogues. 'Signifier' in this case in the form of visual/scenes and sound as a sound image or sound. Whereas the 'signified' here is a description of the concept which is the basis of sound and visual imagery. For the two representations that appear based on Stuart Hall's representation theory, namely:

a. The concept of diffable for mental representation.

b. The meaning created by the representation of disabled people achievers, to explain the representation of language.

Impressions to be analyzed are divided into 4 parts/segments, where this division adjusts the segment settings four times, each segment having a duration of about 7-10 minutes.

Segment 1: Suryo Nugroho won 1 gold, 2 silver at the 2018 Asian Para Games

Sign: Scene 1: Badminton Asian Para Games 2018; Verbal: Self-profile Introduction.

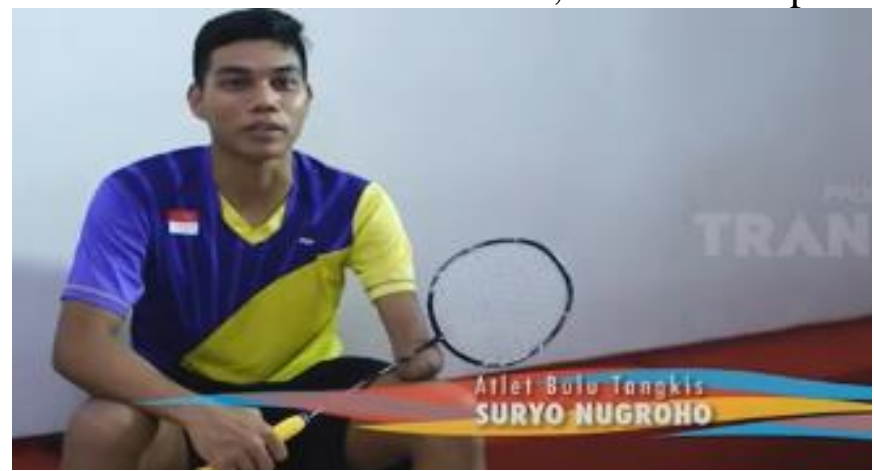

Figure 1. Suryo Nugroho Disability Athlete (source: Trans 7 Official, 2018)

Verbal: Suryo: "My name is Suryo Nugroho, 21 years old, I am a paragames badminton athlete, as long as I am Central Java. I was a normal athlete and in 2006 I had a motorcycle accident and had to be amputated, and I also had a vacuum for 3 years and in 2009 I started training again and took part in a disability tournament." The signified explained that the badminton athlete with disabilities was named Suryo Nugroho. 
Sign: Scene 2: Suryo Nugroho--Badminton Athlete Asian Para Games 2018 is chatting and smiling with hosts 'Hitam Putih' Deddy Corbuzier and Co-Hosts Rico Ceper and Fanny Ghassany; Verbal: questions and answers interspersed with laughter.

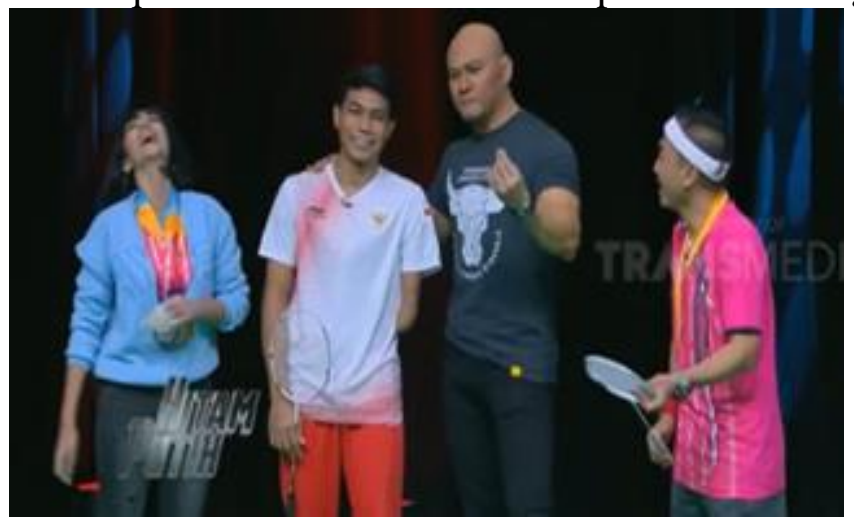

Figure 2. Suryo Nugroho chatting and smiling with the Host 'Hitam Putih' (source: Trans 7 Official, 2018)

Verbal: Suryo: "... parents who support ..."; Deddy: "But I don't care about that, I care about how much money you get, how much is the bonus? We know that gold one point five (1.5 billion) means 750 each person or how many people?"; Rico: "What is the total?"; Suryo: "one ... six fifty"; Fanny: "Great"; Deddy: "Woow." The signified that appeared showed Suryo Nugroho being asked alternately between the main Host and CoHost about the reward. Then Suryo Nugroho told the story of his struggle to rise again from the breakup, suddenly interrupted by Deddy with an expression of indifference about mental awakening, but more interested in the tournament prize bonus amount, and the question was enthusiastically answered by Rico and Fanny with the three hosts showing their surprise. with the amount of prize money the athlete gets.

Segment 2: Hendi Wirawan--Para Games Chess Athlete, 3 gold medalist; and Edy Suryanto--Para Games Chess Athlete, won 3 gold 1 bronze medals

Sign: Scene 1: Two Chess Athletes of the 2018 Asian Para Games are chatting and showing sports equipment/chess boards and special pawns to Deddy Corbuzier and CoHosts Rico Ceper and Fanny Ghassany; Verbal: how to play a chessboard specifically for the blind athletes.

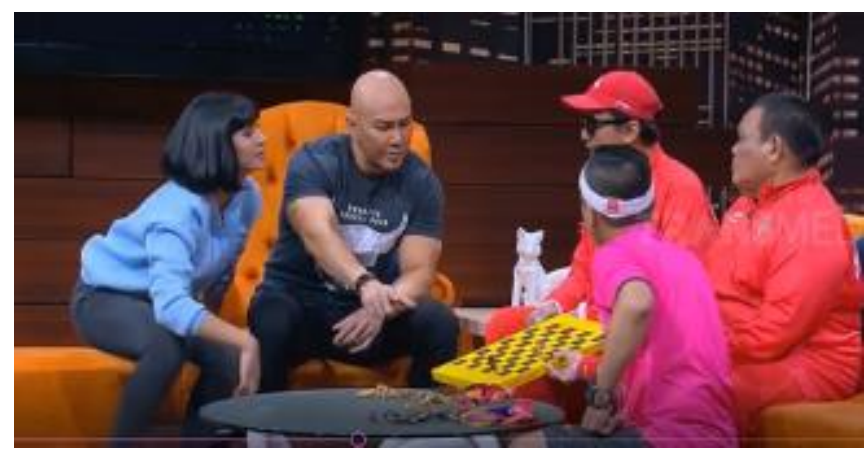

Figure 3. Two Chess Athletes of the 2018 Asian Para Games in 'Hitam Putih' (source: Trans 7 Official, 2018)

Verbal: Deddy: "Those are holes, how to they or their opponents the way forward?"; Hendi:"The chess board has black and white, so the black rises one level"; Fanny: "Ooo this one? ... Oh yeah, more up "; Rico: "Ooo yes ... can be held, the wood has risen a little ..." Signified: The Host and Co-Host shows showed enthusiasm on the chessboard, and the two disabled athletes showed it. Deddy and his Co-host tried to touch the chess board, 
observing the difference with a regular board. Highlight the difference and emphasize the importance of palpation. The conversation also highlights the importance of strong memories specifically for diffable chess athletes.

Sign: Scene 2: Two Chess Athletes of the 2018 Asian Para Games sitting on the couch of the 'Hitam Putih' at the opening event ceremony; Verbal: introducing two gold-winning by diffable chess athletes.

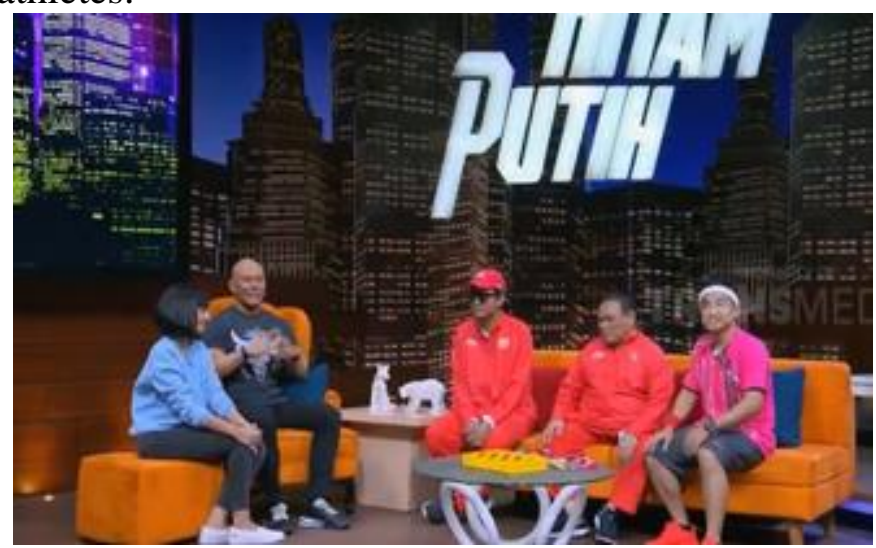

Figure 4. Two Chess Athletes of the 2018 Asian Para Games in 'Hitam Putih' opening scene (source: Trans 7 Official, 2018)

Host Deddy Corbuzier greeted the names of the two athletes as well as the number of gold and other medals that were brought home, after which Co-Host immediately asked about prizes or bonuses.

Verbal: Deddy: "We congratulate to Edy and Hendi for 3 gold coins each, but what makes me curious about how much money? That is the most important, that was first"; Fanny: "What's ... yes right away?"; Rico: "How much is it from the government? ... appreciation"; Deddy: "If Hendi is 3 gold, how much is the total bonuses?"; Hendi: "...." (speechless); Deddy: "... (wait a moment) how much is the bonus?"; Hendi: "Yes, not bad ..."; Deddy: "Yes, how much Sir?"; Hendi: "Well ... yes around three billion"; Deddy: "hahahahaha ..."; Fanny: "If the three billion is Hendy, how about Edy?"; Edy: "If I were three point two fifty billion"; Deddy + Fanny + Rico: "Wow ... hahahaha." Audience in the studio: thunderous applause. The signified that this dialogue expressly shows a great interest in curiosity for the amount of material/prize money obtained from the winners of the two athletes in the 2018 Asian Para Games. Host and Co-Host also showed facial expressions that were eagerly waiting for an answer because Hendi momentarily implied embarrassment and was reluctant to answer. This condition actually makes Deddy as the main Host, chasing to ask again about the amount of bonus money they received. When getting answers, the host shows a satisfied expression marked by 'laughing out loud.'

Segment 3: Putri Aulia, Ni Made Arianti daughter, and Endang Sari Sitorus--with impaired vision--the gold medalist in the sport of running in the Asian Para Games 2018 


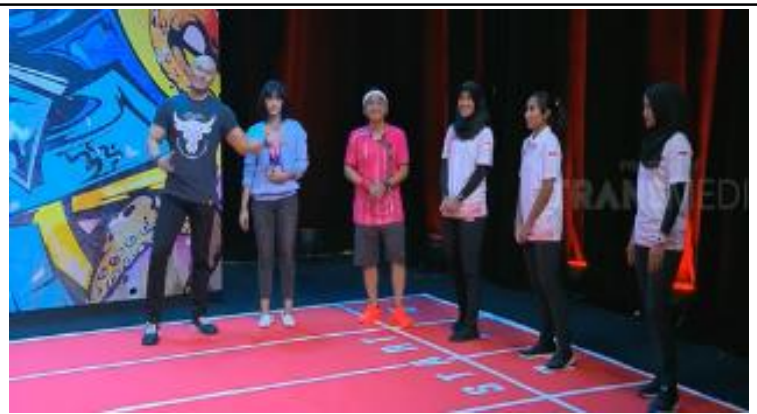

Figure 5. Three Runners Athletes of the 2018 Asian Para Games on the Track 'Hitam Putih' (source: Trans 7 Official, 2018)

Verbal: Deddy: "Okay, I was just wondering, what's the difference ... about 'ready to start the race'?"; Rico: "ready to start the race' that they start the overpass, if there is a normal start there is a start block, they put on the track ... if they come out of the track it is disqualified, because they have limited vision ... right? (asking 3 female athletes) "; 3 running athletes: "correct ..."; Deddy: "Okay ... they have limited vision, who are they?, the following are profiles of the three heroines on my left." Signified: this conversation shows that the three athletes have different behavior from other 'normal' people who are often mentioned by Co-Hosts. They are increasingly being shown about 'shortcomings' and 'differences', indirectly they are being compared to athletes 'normal.' The Co-Host also sought approval from the three female athletes that her opinion was "correct."

Segment 4: Suryo Nugroho, Hendi Wirawan, Edy Sutrisno, Putri Aulia, Ni Made Arianti Putri, and Endang Sari Sitorus, brought together in one scene against the background of the event's name 'Hitam Putih.'

Sign: Scene 1: Three Runners Athletes of the 2018 Asian Para Games, two Blind Chess Athletes, and a Disabled Badminton Player sitting on a long sofa together with Host and Co-Host with the background of the event name; Verbal: confirms the truth of the news regarding problematic bonuses and awards from the government of Indonesia to the speakers.

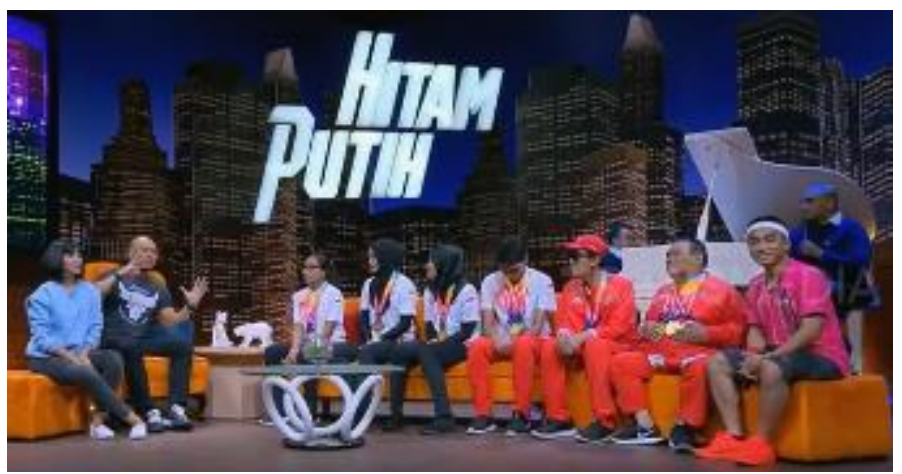

Figure 6. Six Disability Athletes brought together in one scene 'Hitam Putih' (source: Trans 7 Official, 2018)

Verbal: Deddy: "Okay now we will begin to answer questions from the news circulating ... one by one we ask the news whether it is true or not ... please, Rico ... please Fanny"; Rico: "They said they were promised to be Candidates for Civil Servants or CPNS ... correct or not?; Suryo: "That's right, since 2015 I have been appointed CPNS"; Deddy: "Then about the prize or bonus, is it the same as Asian games? ... How much are the total prizes?; Putri: "One seven fifty billion"; Deddy: "How many are you?"; Endang: "Two hundred and fifty million"; Deddy: "How many are you?"; Ariyanti: "One billion." The signified showed that all the speakers, the Asian Para Games athletes who 
had been interviewed by each segment, complete with the gold, silver and bronze medals that he got. The dialogues that appeared in this particular segment led all questions about the truth of the news circulating in the community. Whether or not the hoax occurs about the deduction of bonuses, the matter of promises to be appointed as CPNS by the state, about changes in the amount of competition from the past, and again the Host and CoHost gives a large question space for the amount of bonus amount given by the state. The interviewees were also asked questions about their desires after receiving large prize money, whatever he would do. This shows that the talk show is trying to showcase government services and emphasizes that prizes can turn them into 'better people.'

Furthermore, based on an analysis using Saussure's semiotics (Saussure, 1966), the data obtained on this talk show shows that there is a tendency to interpret disabled athletes who have not been fully placed on the fulfillment of Human Rights and prioritize equality (right based). more emphasis on the approach 'charity based' or still see the unequal position between the diffable and non-diffable, seeing the diffable not as a human being as a whole, but with a compassionate approach in meeting their needs. Dialogues that arise regarding the flashback why disability, a matter of the athlete's beginnings being 'incomplete' poured in from the beginning and became a media way to build stories and audience empathy. The scenes that are shown also affirm that the body's wholeness is special because it is different.

Since the first segment empathy was built through the profiles of all the athletes present at the event. Suryo Nugroho who clearly stated that "I was born normally," "after the accident I had to be amputated and as a result only had one hand" became one of the dialogues that bound the eyes and ears of the viewers to continue to listen to the event. Also in the second segment came the life story Hendi, who suffered blindness due to a misdiagnosis from a doctor who suspected cataracts, leading to damage to the left eye's retina. The incident was experienced by Hendi at the age of 15 years. With blindness in his left eye, Hendi continued to spend his teenage years cheerfully, but a few months later he had to lose his eyesight again due to his right eye being hit by the ball while playing soccer. Whereas Edy Suryanto experienced blindness due to a tumor on his head which required Edy to be operated on and to have a blindness effect on his childhood cooking. His condition was the same with female runners who had different stories and ended up with their vision problems. Everything is built by showing scenes they are practicing routinely, and footage heroic when competing, with narrative profiles and a series of sentences that captivate the audience for the sake of a human story that is struggling whole heartedly with the situation shown in the show is 'incomplete body/imperfect/unlike other normal humans.'

The story of the flashback is full of struggles and a series of questions and statements about prizes shows that the mass media is building empathy that is moving blue so that the show remains favored by most Indonesian people who live in a culture of mutual cooperation full of empathy. The cultural capital of caring and easy to collapse compassion by some of the people of Indonesia is used by the media to get the full attention of the audience. Regarding scenes and dialogues that are tarnishing about bonuses, this is related to cultures that still favor material prizes as rewards for achievement.

The material value becomes the main, giving gifts is reasonable for those who excel especially in a state of disability. Host and Co-Host's questions about the state's contribution to their contribution also confirm that the community can sue the government 
for the achievements of these people who are deemed incomplete but with achievements. How many countries give to those who are seen as incomplete, because they fight wholeheartedly for. It was this narrative that finally appeared in the 'Talk Show Atlet Difabel Berprestasi di Hitam Putih (Talk Show Athletes with Disabilities with Achievements in 'Hitam Putih')'. At the end of the final segment, the final Host of the Main Host said about the importance of watching this program, because it inspired many to backfire on the labeling that was still used by television. Deddy's words: "They inspire, they can ... why we can't?" increasingly placing different humanitarian standards for persons with disabilities.

The host also emphasized again clearly the importance of the struggle for those who were considered 'not intact', namely by showing the shirt he wore that read 'progress through pain, strenght to struggle.' This sends a message to viewers that those with disabilities will go through a hard struggle, to be able to live let alone be strong. An ending that seems very inspiring, but actually is nothing more than painful labeling of persons with disabilities. Looking at the diffable as his right as a human being (right based), it seems that it is still difficult to show on television. Disability, in this case, disabled athletes without power must be willing to be received to receive awards for their achievements with a makeup 'charity based' because the packaging is preferred by viewers and will automatically boost ratings.

\section{Conclusion}

The results of the analysis show that disability in the 'Hitam Putih " program Trans7, the 2018 Asian Athlete Games edition is still a show designed in such a way by the creative team solely to engage the interest of the viewer's attention. Everything remains a market commodification and there is still a high element of compassion and inspiration for others (inspirational porn) as stated by Stella Young (TED, 2014). Maintaining the rating and share of private television requires team creativity and accuracy in utilizing the momentum of the Asian Para Games is the answer to how creative teams can move quickly and elegantly to 'sell' inspirational stories but without seeming to patronize the audience. This show is still an entertainment but wrapped with information about the disability.

This research is a note for those who work in the broadcasting industry, that the media are responsible for determining which viewpoints will be perpetuated in society towards persons with disabilities. As a side note, sometimes the mass media also forget the protection of the disabled and other minority groups. The presence of the diffable on the screen as a resource person for the talk show program is certainly regulated by the Indonesian Broadcasting Commission (KPI) in the Broadcasting Behavior Guidelines Broadcast Program Standards (P3-SPS) Article 15 sections 1 and 2 concerning the obligation to pay attention to and protect the rights and interests of minority groups. In fact, television stations still neatly keep the rules and seem to read enough without doing. Television has indeed become a connecting window between the real condition of diffable people with their representation, but the media should also enlighten all viewers (general public, government, community organizations, etcetera) that a diffable person will be increasingly viewed differently because he is not supported by environmental facilities.

There is no excessive euphoria if the environment and access on all sides of life always take into account the needs of the disabled and not left alone so that eventually circumstances force it to be 'different.' An achievement that is created is fairness that becomes unnatural because they are distinguished by the environment, into objects that 
are worthy of pity. Likewise with media content, ideally the person with disabilities is no longer only displayed in a happy and sad earthquake that drains emotions, but also gives space to the human side. who have the same rights as the others. An appreciation of the full human right, so that it will not appear again to appreciate the achievements of a person with a disability with only a measure of money or material. Meanwhile, for further research this study might be used as a basis for research/state of the art, related to the study of the political economy of the media associated with cultural construction.

\section{Acknowledgments}

The Research Team would like to thank the Faculty of Information Technology and Communication, and also thank you to LPPM--Universitas Semarang for providing opportunities, and operational assistance during this research.

\section{References}

Anonymous. (2019). International Day of Persons with Disabilities. Retrieved August 20, 2019, from World Health Organization website: https://www.who.int/newsroom/events/detail/2020/12/03/default-calendar/international-day-of-personswith-disabilities

Baskin, A. (2006). Jurnalistik Televisi Teori dan Praktik. Bandung: Simbiosa Rekatama Media.

Bungin, B. (2012). Penelitian Kualitatif Komunikasi,Ekonomi, Kebijakan Publik, dan Ilmu Sosial Lainnya. Jaka: Kencana Prenada Media Group.

Hall, S. (1997). Theory of Representation. London: Sage Publications.

Hunt, P. (1966). STIGMA The Experience of Disability. London: GEOFFREY CHAPMAN.

Moeloeng, L. J. (2017). Metodologi Penelitian Kualitatif (Edisi Revisi). Bandung: Remaja Rosdakarya.

Nurcahya, H. R., Hafiar, H., \& Nugraha, A. R. (2018). Representation of Orientalism in Sunsilk Print Advertising. Jurnal The Messenger, 10(2), 150-161. https://doi.org/10.26623/themessenger.v10i2.744

Salim, I. (2018). Membaca Data Disabilitas Iindonesia Melalui Supas 2015: 'Penyandang disabilitas' atau 'Orang Dengan Beragam Kesulitan'? Retrieved March 11, 2019, from 26 February 2018 website: https://www.solider.id/baca/4280-membaca-datadisabilitas-iindonesia-supas-2015-penyandang-disabilitas-orang-beragam

Saussure, F. De. (1966). Course in General Linguistics (C. Bally, A. Sechehaye, \& W. Baskin, Eds.). New York: Mc Graw-Hill.

Sobur, A. (2009). Analisis Teks Media. Bandung: Remaja Rosdakarya.

Sobur, A. (2011). Psikologi Umum. Bandung: Pustaka Setia.

Sobur, A. (2016). Semiotika Komunikasi (6th ed.). bandung: Remaja Rosdakarya.

Sugiyono. (2009). Memahami Penelitian Kualitatif. Bandung: Alfabeta.

Syahputra, I. (2013). Rezim media: pergulatan demokrasi, jurnalisme, dan infotainment dalam industri televisi. Jakarta: Gramedia Pustaka Utama.

TED. (2014). I'm not your inspiration, thank you very much | Stella Young. Retrieved March 11, 2019, from 9 June 2014 website: https://www.youtube.com/watch?v=8K9Gg164Bsw\&feature=youtu.be

Thaniago, R. (2018). Bolehkah Saya Menjumpai Difabel di Media Dengan Layak? Retrieved March 11, 2019, from 12 December 2018 website: 
http://www.remotivi.or.id/amatan/503/Bolehkah-Saya-Menjumpai-Difabel-diMedia-dengan-Layak?

Trans 7 Official. (2018). Hebat! Atlet Catur Tunanetra Raih 3 Emas | HITAM PUTIH (16/10/18). Retrieved from Youtube website: https://www.youtube.com/watch?v=ke9axDrYzbc

Watie, E. D. S. (2010). Representasi Wanita Dalam Media Massa Masa Kini. Jurnal The Messenger, 2(2), 1-10. https://doi.org/10.26623/themessenger.v2i2.297

Wood, L. (2014). Critical Analysis: Media Representation of Disability. Retrieved March 11, 2019, from 2014 website: http://www.disabilityplanet.co.uk/criticalanalysis.html

Zhang, L., \& Haller, B. (2013). "Consuming Image: How Mass Media Impact the Identity of People with Disabilities.” Communication Quarterly, 61(3), 319-334. 